\title{
Challenges and Coping Strategies of College students' Network Ideological and Political Education in “Internet Plus" Age
}

\author{
Xin Yuan \\ Zao zhuang university
}

Keywords: Internet Plus”, colleges and universities, college students, network ideological and political education

\begin{abstract}
Internet Plus" is one national development plan that suggested by Premier Li Keqiang. "Internet Plus" is the major impetus to promote the various revolution and development, which is based on the society economic development. The college students' network ideological and political education in "Internet Plus" age is facing the development chance of modern information technology as well as the network security, harmful network information and the corrupt thought. This article will aim at the current development of the "Internet Plus" age, and discuss the college students' network ideological and political education, then find out the solutions at the same time.
\end{abstract}

\section{Introduction}

The newly issued Opinions on strengthening and improving college students' ideological and political education clearly defined the rules of network ideological and political education in colleges and universities. The college students' network ideological and political education under the "Internet Plus" age should rigid adherence to the campus network and develops the education of socialist core values. The construction of college students' network ideological and political education, should revolves around students' learning, life and lead the students' political thought in the right way, then promote the construction of network information management of colleges and universities.

\section{Connotation and age characteristics of the "Internet Plus"}

Premier Li Keqiang suggested "Internet Plus" in the Report on the Work of the Government on March 3. 2015. "Internet Plus" became the primary type of the national economy development from here. "Internet Plus" relied on the strong internet and cloud computing resources. It can complete the various industries' communication through the data integration in order to realize the social innovation. "Internet Plus" is one social communication activity in politics, economy, society, ecology and other aspects. It is the ultimate development direction of the times and the main development concept is to share together, save energy and create innovation. "Internet Plus" is the combination of traditional industry and the internet information technology. TaoBao is the development of "Department stores + Internet", Meituan is the development of "Restaurant + Internet" and DiDi is the development of "Traffic + Internet". These development models have achieved good economic benefits.

Big data, cloud computing and information communication have completed the upgrading of traditional industries. From the perspective of online ideological and political education, "Internet plus" provides a broad platform for the education development. Ideological and political education should use the information technology platform to reform education model. It can establish one Ideological and political ecology with open and inclusive to convey ideological and political ideas in an open and inclusive manner. The college students' network ideological and political education in "Internet Plus" age faces both development opportunities and potential challenges and risks. The 
colleges and universities should grasp the advantages of education resources provided by "Internet Plus" and carry out ideological and political campaigns. At the same time, it is important to be aware of the bad thoughts and the external network information, and the erosion of students' ideological and political values. Moreover, it is possible to make timely corrections and guidance to them.

\section{The definition and connotation of college students' network ideological and political education}

The college students' network ideological and political education relies on the platform of "Internet Plus". Until July 2017, the number of Chinese Internet users exceeded to 750 million for the first time. The Internet penetration rate reaches 51.7\%, with 675 million mobile Internet users and 161 million Internet users of the college students. The average weekly online time is 26.5 hours. The above data shows that college students are the main group of Internet application. Therefore, the college students' network ideological and political education has to be realized through the network media. The interactivity, openness and convenience of "Internet Plus" provides a platform for the education development. Colleges and universities can establish the campus network, the school's official website, the ideological and political teaching website, and learning communication platform. It will promote students' ideological and political education in colleges and universities, train students' correct ideological values, and the positive study and life style.

\section{Opportunities and challenges of college students' network ideological and political education}

\section{Opportunities of college students' network ideological and political education.}

Ideology politics teaching is the core center of the traditional ideological and political education. Students obtain the knowledge through classroom teaching. This way of teaching cannot grasp the essence in the short class. Moreover, the teaching time and place will limit students' understanding if they are out of the class. The network class has great interactivity and openness with Immediacy. Students can receive the ideological and political knowledge anytime and anywhere. They can find the teaching plan online and test the learning content. Some colleges and universities has built digital library, electronic editions of periodicals, electronic newspapers and other various materials on the network. It is easy to login the Individual account and then study the knowledge. A large number of ideological and political teaching content, cases, materials and stories can help students to understand the connotation of "socialist core values". It will help students to form a complete ideological and political theory system, then complete their personal values construction. The spread of ideological and political education in the network can create a good ideological and political atmosphere, promote the ideological and political construction and development of colleges and universities.

\section{Challenges of college students' network ideological and political education}

The negative effect of bad network information on college students' political views. "Internet Plus" is one open communication platform, which is being influenced and eroded by the bad network information in every aspect. Although the virtual Internet space has the openness, it has hidden characteristics for the use of personal mobile Internet. College students are still in the development stage of physical and mental development. They are not good at resolving bad thoughts and concepts, and they are vulnerable to external information. There are all kinds of advertisements, false ideas and false information in the network, and there are still many deficiencies in the state's supervision of the Internet. The corruption and negative information in the supervision and management loopholes can have serious negative effects on college students' ideological and political views.

The corrosive effect of western Internet culture on college students' political ideas. The concept of "money worship, human rights equality and the open mind between men and women" in western Internet culture has a serious negative effect on college students' ideological and political values. The western network culture uses film, e-books, electronic music and electronic shopping as the network media to convey the values of "human rights and freedom" to the students. This 
beautified life style and human rights values are not the same as the western real life style and values. These ideas advocate self-centered individualism, self-value through the possession of others, and the subjectivity of individuals through the conquest of nature. The western "money worship", "individualism" and other decadent class ideas has corrupted the pure heart of college students, make college students ideological and political education appear corresponding deviation. Therefore, colleges and universities should use socialist core values to cultivate the values of college students' network ideology.

The "Internet Plus" is weak in the orientation function of social public opinion .At present, China's Internet network lacks of proper social public opinion guidance, and some leading political ideas are annihilated in numerous network information. In the case of college students' own moral restraint, their randomness in the use of the Internet poses a great potential risk. Most students have Internet addiction, which mainly use the Internet to satisfy their personal life communication and entertainment, while ignoring the ideological and political learning. Some students even ignore normal work and study because they are addicted to online games and social chatting. If things continue this way, students' dependence on the virtual Internet can be caused by the lack of real emotional communication, which can even lead to serious problems of actual communication.

Multiple education resources erode the ideological and political education. The "Internet Plus" age realizes the exchange and sharing of the global education resources. On one hand, it promoted the communication and dissemination of knowledge. On the other hand, it also cause some damage on college students' ideological and political education. Excellent education resources have great appeal to the students. With the gradual formation of economic globalization, toefl, ielts, GRE and other English tests become the focus of students' learning. Students will spend most of their energy on the online courses. Ideological and political education can only be a foil for professional knowledge learning. This great heat of English and other technical education makes gradually weaken of the ideological and political education, and gradually increases of the collision of various cultural ideas. In this kind of open "Internet Plus" development mode, students will lost in ideological and political ideas and values. If we neither control nor restrain the foreign cultural input, these cultural erosion will fundamentally threaten our country's ideological and political education work.

\section{Coping strategies of college students' network ideological and political education in "Internet Plus" age}

Construct a perfect network ideological and political education platform.College students' ideological and political education includes socialist core values, patriotism, mental health, moral philosophy and other aspects. The ideological and political education need to develop a perfect plan. Network ideological and political education takes Opinions on Strengthening and Improving College Students' Ideological and Political Education as a guide, and complete the task of ideological and political education through overall planning phase. Each college should build its own online ideological and political education platform on the basis of the university's ideological and political education website, and focus on it. "Internet Plus" network contains a large number of ideological and political education contents. In the network of colleges and universities should establish campus network, the school's official website, ideological and political teaching network. Teachers also should establish their own learning communication platform to facilitate students' ideological and political learning content acquisition. Only in the basis of overall planning, the teaching task can be subdivided, and it will complete the ideological and political teaching tasks of various regulations.

Perfect the system of network ideological and political education. Campus network management departments should manage and set up websites in campus network according to the relevant regulations of the state. The education system should start from information management. It should filter and block the pornographic websites and reactionary information, supervise and manage the students' online behaviors. Establish the strict system of audit and supervision of network information is the only way to correctly guide the students' ideological and political ideas, 
and create a healthy and upward network ideology and politics education atmosphere. At the same time, the campus network should report the major events of the country, explain and clarify some sensitive political issues to eliminate the negative effects of ideological and political education.

Content innovation of ideological and political education .Content innovation of ideological and political education is the key of the education communication. The reform and innovation of education content and education method can attract students' attention to a certain extent and help them understand the real meaning of ideological and political education. For example, the ideological and political ideas' communication in the "Internet plus" situation should be based on the political content and ideology of students' life, which can lead to students' interest in reading and resonance of ideas. In the form of ideological and political education, we should use the pictures, words, video and so on of "Internet Plus" to carry out the transmission of the ideological and political education. In ideological and political education content editor, we need avoid policy document reading of rhetoric type, use language and content of the student's enjoy, deep in their ideology and values, in order to guide the students' ideological and political study. At the same time, we can also use QQ, Weibo and WeChat to complete the transmission and solution of education content. College teachers should always pay attention to the feedback of the education platform and answer questions. Based on the students' psychological expectation, the online ideological and political content can be welcomed and affirmed by the students, in order to cultivate students' strong ideological and political values.

\section{Conclusion}

The network and data of "Internet Plus" have promoted the development and integration of the industry. "Internet Plus" develop and integrate the traditional ideological and political teaching mode. As a personal network space, the Internet has a great personal preference in the selection of online content and information. Therefore, the education restriction and standard of Internet ideology and politics education should be the main content of college students' ideological and political education. At the same time, universities should take advantage of the big data and information dissemination of "Internet plus" to promote the healthy development of the education.

\section{References}

[1] Zhang Daoming, Liu Xueli, Exploration on Construction of Network Ideology and Culture Position in Clleges in the Times of "Internet +",Journal of Urumqi Vocational University,2015,4, p.8-10

[2] Yu Qiuye, Difficulties and Outlet of Colleges Students' Ideological and Political Education in the Times of "Internet plus", Cognition and Practice, 2016,10,p.113-116

[3] Yan Xiaomin, Ideological and Political Education Searching in the Colleges of "Internet +" Age, Management \& Technology of SME, 2016,29,p.155-156

[4] Ma Kun, Ideological and Political Work in Railway Enterprise in the times of "Internet +", Global Market Information Guide, 2016,4,p.112-113

[5] Han Yuling, The Promotion of Teachers' Media Literacy in Ideological and Political Theory Course in Colleges and Universities Based on the "Internet +", Journal of Hunan Industry Polytechnic, 2017,2,p118-120

[6] Zhu Qianbo, Estabishmen of Ideological and Political Work in Vocational Schools Students in the Times of "Internet plus", Training in China, 2015,6,p.16-17

[7] Zhang Yang, Analysis of Cultural Environment about Colleges' Ideological and Political Education in the Times of "Internet plus", Journal of PLA Nanjing Institute of Politics, 2016,6,p.137-139 
[8] Guo Peiqi, Lin Jun, Xia Huan, Zhang Jian, Research on the Countermeasures of College Students' Ideological and Political Strategies in the Era of Mobile Internet, Journal of Seeking Knowledge Guide, 2016,15,p.8-9 